\title{
Estimated Cost of Production for Medical Cannabis (Cannabis sativa L.) in Greece
}

\author{
Chariklia CHATZIGIANNI ${ }^{1}$, Ioannis ROUSSIS ${ }^{1}$, Christos T. PAPADAS ${ }^{2}$, Stella KARIDOGIANNI ${ }^{1}$, Varvara \\ KOUNELI $^{1}$, Ioanna KAKABOUKI ${ }^{1}$, Antigolena FOLINA ${ }^{1}$, Panayiota PAPASTYLIANOU ${ }^{1}$, Dimitrios \\ BILALIS ${ }^{1 *}$
}

\begin{abstract}
${ }^{1}$ Agricultural University of Athens, School of Plant Sciences, Department of Crop Science, Laboratory of Agronomy, 75 Iera Odos Str., 11855 Athens, Greece.

${ }^{2}$ Agricultural University of Athens, School of Applied Economics and Social Sciences, Department of Agricultural Economics and Rural Development, Laboratory of Rural Economic Development, 75 Iera Odos Str., 11855 Athens, Greece.

*corresponding author: bilalisdimitrios@gmail.com
\end{abstract}

BulletinUASVM Horticulture 77(1) / 2020

Print ISSN 1843-5254, Electronic ISSN 1843-5394

DOI:10.15835/buasvmcn-hort: 2019.0017

\begin{abstract}
In recent years, cannabis has raised public awareness in many countries worldwide about its medical uses. The European cannabis market reached its peak during 2018 with investments of 500 million $€$. Greece introduced Law 4523/2018, which regulates the production and processing of medical cannabis. A start-up business plan was drawn up for a medical cannabis operation owned a 1 ha greenhouse to estimate the start-up costs and the costs of cultivating and processing medical cannabis under greenhouse conditions in Greece. The results of the present study revealed that the investment was estimated at 4,960,044 €. Net profit in the first year amounted to $3,584,621.70 €$, while the annual net profits from the second to the tenth year amounted to approximately 7.07 billion. The Net Present Value with a value of $45,425,241.24 €$ is positive and the internal rate of return (IRR) is 94.14\%, which means that the investment can be characterized as profitable.
\end{abstract}

Keywords: business plan, economic analysis, greenhouse cultivation, medical-cannabis facility, profitability

\section{Introduction}

Cannabis (Cannabis sativa L.) is a plant species mainly associated with its psychoactive use, which is due to the substance of tetrahydrocannabinol (THC). THC is the main psychoactive compound and the most well-known. As a result, it has several therapeutic properties that make the plant one of the most talked about plant species in the world (Kinghorn et al., 2017).

In recent years, cannabis has raised public awareness in many countries worldwide about its medical uses. This has subsequently led to a number of jurisdictions, either by decriminalizing cannabis or legalizing it for medicinal use, with some countries moving towards full legalization. With the growing acceptance of cannabis by the public, it is possible to create an entire cannabis industry to meet consumer demand and preferences, such as demand for cannabis-based medicines (EverBlu Capital, 2017).

The European cannabis market reached its peak during 2018, with investments of 500 million $€$. This market has so far focused on the distribution of medical cannabis licenses. Across 
Table 1. Arrangement of medical cannabis integrated production unit owned a 1 ha greenhouse

\begin{tabular}{|c|c|c|c|}
\hline \multicolumn{2}{|r|}{ Description } & \multirow{2}{*}{ Land Area $\left(\mathrm{m}^{2}\right)$} & \multirow{2}{*}{ Cultivation Area $\left(\mathrm{m}^{2}\right)$} \\
\hline I. & Greenhouse facilities & & \\
\hline I.1 & Vegetation zones & 5,916 & $3,549.6$ \\
\hline $\mathrm{I} .2$ & Flowering zones & 8,875 & 5,325 \\
\hline \multirow[t]{2}{*}{ I.3 } & Mechanical equipment area & 640 & - \\
\hline & Subtotal & 15,431 & $8,874.6$ \\
\hline II. & Building premises & & \\
\hline II.1 & Mother Plants - Clone area & 800 & 700 \\
\hline II.2 & Service area & 300 & - \\
\hline II.3 & Trimming area & 50 & - \\
\hline II.4 & Drying area & 60 & - \\
\hline II.5 & Packaging area & 170 & - \\
\hline \multirow[t]{2}{*}{ II.6 } & Warehouse area & 300 & - \\
\hline & Subtotal & 1,680 & 700 \\
\hline III. & Exterior premises & & \\
\hline III.1 & Solar disinfection platform & 350 & - \\
\hline III.2 & Soil substrates storage area & 280 & - \\
\hline \multirow[t]{2}{*}{ III.3 } & Ovens area & 60 & - \\
\hline & Subtotal & 690 & - \\
\hline VI. & Other auxiliary premises & & \\
\hline VI.1 & $\begin{array}{l}\text { Offices, restaurants and rooms } \\
\text { (e.g. changing rooms) }\end{array}$ & 1,100 & - \\
\hline & Subtotal & 1,100 & - \\
\hline & Total area $\left(\mathrm{m}^{2}\right)$ & 18,901 & $9,574.6$ \\
\hline
\end{tabular}

Europe, countries are reviewing the application of medical cannabis throughout the region. Countries such as France, the United Kingdom, and Spain are reviewing their current legislation. On the other hand, industry leaders (Germany, Italy and the Netherlands) focus on expanding the existing medical programs (Prohibition Partners, 2019).

In March of 2018, Greece introduced Law $4523 / 2018$, which regulates the production and processing of medical cannabis. This law was applied due to the desire to revitalize the crop industry and to trade in cannabis products. For the granting of approval for installation and authorization, the applicant must submit documents for all stages (from cultivation to processing and production of final medical cannabis products). On the basis of legislation, the cultivation will take place under greenhouse or indoor conditions (Folina et al., 2019). The objectives of this study were to estimate the startup costs and the costs of cultivating and processing medical cannabis under greenhouse conditions in Greece.

\section{Materials and Methods}

A start-up business plan was drawn up for a medical cannabis operation owned a 1 ha greenhouse. The arrangement of this integrated production unit expressed in square meters is presented in Table 1.

The approach was to identify the various stages from infrastructure setup to the manufacturing of medicinal cannabis oil. The analysis was broken up into costs for business start-up, and then for cultivation and processing. For estimation of the total cost of cultivating and manufacturing medicinal cannabis, the present study was based on publicly available literature and research on medicinal cannabis industries in other countries (Caulkins, 2010; Hawken, 2013; Deloitte, 2016). Where data on the cultivation and manufacture of medicinal cannabis was not available, other crop types that exhibit a similar cost structure or cultivation technique to cannabis were used as proxies, such as cherry tomatoes (Laate, 2013). The construction cost was estimated at $41.4 €$ $\mathrm{m}^{-2}$. The equipment cost required for the medical cannabis cultivation (irrigation systems, drainage systems, fans, lighting, and heating systems) was set at $107.5 € \mathrm{~m}^{-2}$. The land price was $8809.5 €$ per ha. The security cost amounted to $17 € \mathrm{~m}^{-2}$. The cost of labor was estimated at $618 €$ per kg of dry inflorescences or $445 € \mathrm{~m}^{-2}$. The shipping cost was set at $0.25 €$ per kg of dry inflorescences. 
Table 2. SWOT analysis for greenhouse medical cannabis production in Greece

\begin{tabular}{|c|c|}
\hline Strengths & Weaknesses \\
\hline $\begin{array}{l}\text { - Ideal environment and climate conditions } \\
\text { - Possibility of creating mother plants/seeds } \\
\text { with high genetic standards } \\
\text { - Direct access to the European market } \\
\text { - Lower average production from other } \\
\text { countries } \\
\text { - Comparative advantage at a technical level - } \\
\text { creating strategic alliances } \\
\text { - Direct access to public authorities } \\
\text { - Updated information about developments in } \\
\text { the institutional framework }\end{array}$ & $\begin{array}{c}\text { - Legislative gaps and a strict institutional } \\
\text { framework for providing authorizations / operations } \\
\text { - Institutional risk of the license framework for } \\
\text { extension and modernization } \\
\text { - Participation of different and interested } \\
\text { institutions/ ministries/ services. } \\
\text { - Lack of comparative domestic productivity/ } \\
\text { profitability } \\
\text { - No common procedures in cultivation and } \\
\text { production in comparison to other plant species } \\
\text { - Lack of experience from the public authorities } \\
\text { - Lacks in production from large markets on the } \\
\text { legal framework. }\end{array}$ \\
\hline Opportunities & Threats \\
\hline $\begin{array}{l}\text { - High and growing demand from the } \\
\text { European and international markets } \\
\text { - Easy corporate investments with rapid } \\
\text { decrease of invested capital } \\
\text { - Export capacity under the institutional } \\
\text { framework }\end{array}$ & $\begin{array}{c}\text { - The unable policy and financial situation in Greece } \\
\text { - The issue of limited number of licenses } \\
\text { - The possible "negative" reaction of pharmaceutical } \\
\text { companies } \\
\text { - Possibility of direct/ indirect income of } \\
\text { competitive foreign companies } \\
\text { - Creation of "cartel" conditions because of the } \\
\text { oligopolistic structures of industry }\end{array}$ \\
\hline
\end{tabular}

Regarding the consumables cost, it was estimated at $434 € \mathrm{~m}^{-2}$. About $80 \%$ of this cost, it is related to nutrients and the remaining $20 \%$ to pesticides. Costs of licenses, taxes and certification costs were estimated at $61.4 € \mathrm{~m}^{-2}$ or $85.2 €$ per $\mathrm{kg}$ of dry inflorescences (Deloitte, 2016).

The calculation of production capacity is based on greenhouse facilities. A three-week period is required to obtain a plant clone derived from the same plant (Miriello, 2017). In the present study, the total number of 1,401 mother plants was divided into three subsets of 467 mother plants each. The weekly production of each mother plant is between 6 and 10 cuttings (estimated at about 7.58 cuttings) (Miriello, 2017). The first harvest of the first year was taken place on the 21st week (Miriello, 2017).

The profitability ratios in the current research were calculated using the following formulas (Wachira et al., 2014; Honoré et al., 2019):

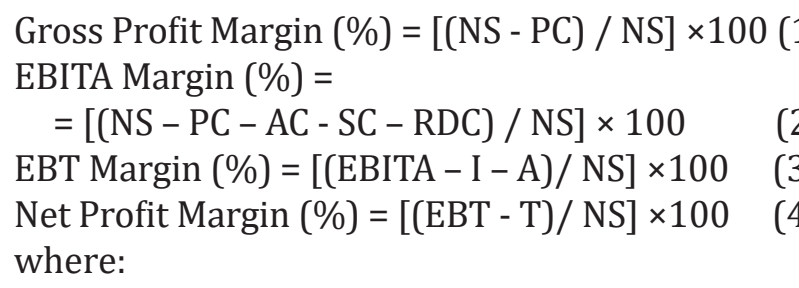

EBITA = Earnings Before Interest, Taxes, and Amortization; EBT $=$ Earnings before taxes and amortization; NS $=$ Net Sales; $\mathrm{PC}=$ Production Costs; $\mathrm{AC}=$ Administrative Costs; $\mathrm{SC}=$ Sale Costs; RDC = Research and Development Costs; $\mathrm{I}=$ Interests of loans and working capital; $\mathrm{A}=$ Amortization and $\mathrm{T}=$ income Tax.

Finally, a SWOT analysis (strengths, weaknesses, opportunities and threats analysis; Tab. 2) was performed to identify the internal and external factors that can have an effect on viability of greenhouse medical cannabis production in Greece.

\section{Results and Discussions}

The total investment budget was estimated at 4,960,044 $€$ and distributed among building installation and infrastructures, mechanicaltechnical equipment, other equipment, and intensive costs in the ratio of $42.28: 51.56: 3.08$ : 3.09 , respectively. A bank loan of 3,968,035.20 €, accounting for $80 \%$ of total investment budget, was needed to complete the project. The long-term loan was estimated to last ten years with the first instalment paid off in the first year of the business. The instalment was determined as a half-year and amounted to $198,401.76 €(+3.6 \%$ interests $)$. 


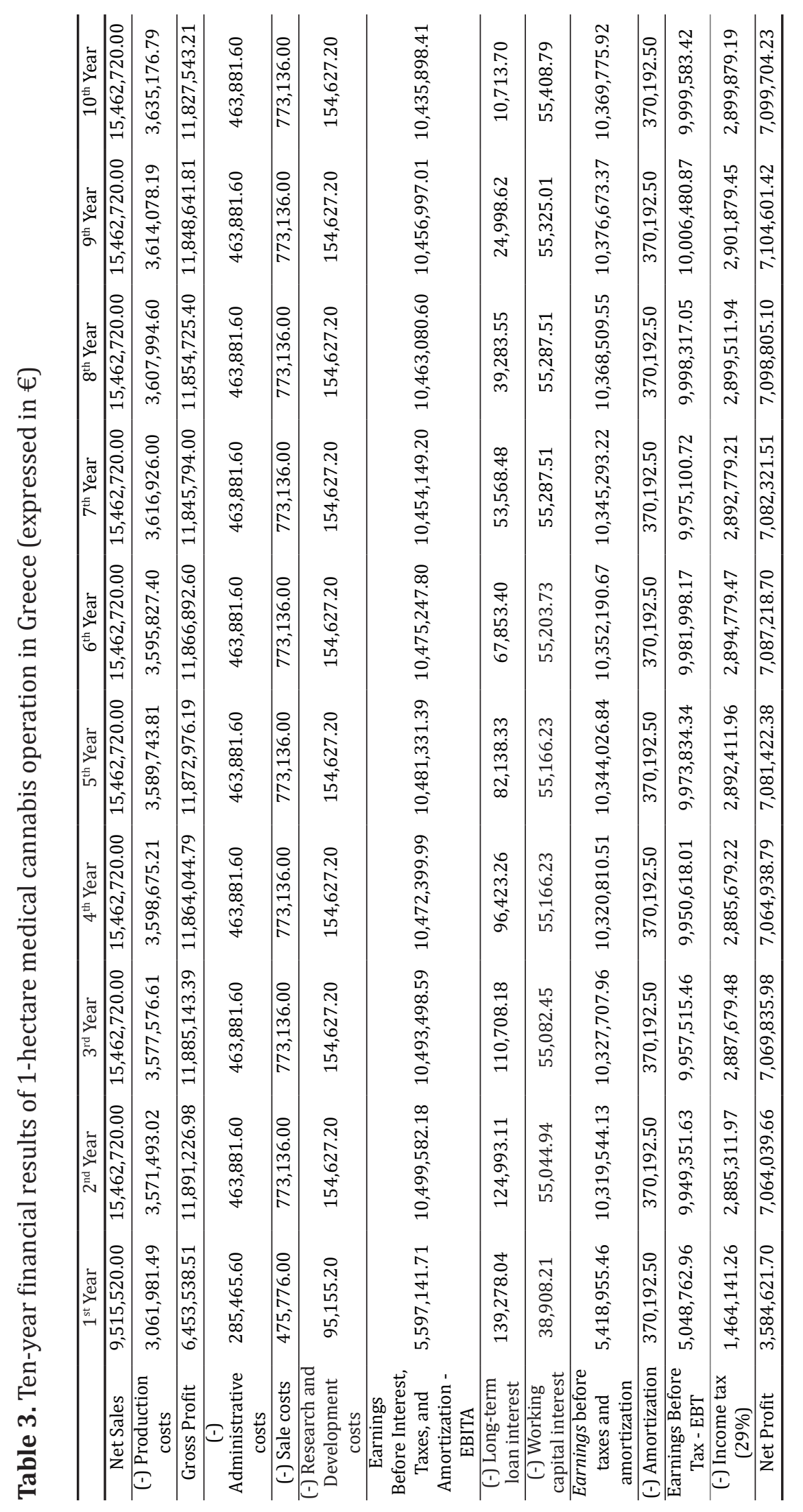


Table 4. Ten-year profitability ratios of 1-hectare medical cannabis operation in Greece

\begin{tabular}{ccccccccccc}
\hline Margin (\%) & $1^{\text {st }}$ Year & $2^{\text {nd }}$ Year & $3^{\text {rd }}$ Year & $4^{\text {th }}$ Year & $5^{\text {th }}$ Year & $6^{\text {th }}$ Year & $7^{\text {th }}$ Year & $8^{\text {th }}$ Year & $9^{\text {th }}$ Year & $10^{\text {th }}$ Year \\
\hline $\begin{array}{c}\text { Gross Profit } \\
\text { Margin }\end{array}$ & 67.82 & 76.90 & 76.86 & 76.73 & 76.78 & 76.75 & 76.61 & 76.67 & 76.63 & 76.49 \\
\hline $\begin{array}{c}\text { Earnings Before } \\
\begin{array}{c}\text { Interest, Taxes, } \\
\text { Amortization - } \\
\text { EBITA Margin }\end{array}\end{array}$ & 58.82 & 67.90 & 67.86 & 67.73 & 67.78 & 67.75 & 67.61 & 67.67 & 67.63 & 67.49 \\
\hline $\begin{array}{c}\text { Earnings Before } \\
\text { Tax - EBT Margin }\end{array}$ & 53.06 & 64.40 & 64.40 & 64.35 & 64.50 & 64.56 & 64.51 & 64.66 & 64.71 & 64.67 \\
\hline Net Profit Margin & 37.67 & 45.72 & 45.72 & 45.69 & 45.80 & 45.83 & 45.80 & 45.91 & 45.95 & 45.91 \\
\hline
\end{tabular}

Site preparation was estimated to last six months. During the first year, the final product of dry inflorescence was estimated at $3.171,84 \mathrm{~kg}$, while, from the second year until the tenth year, it was estimated at $5.154,24 \mathrm{~kg}$ (Miriello, 2017). Taking into account that the price of final product of dry inflorescence was $3.00 €$ per kg (Freeman et al., 2018), the net sales amounted to $9,515,520.00$ $€$ in the first year, and to $15,462,720.00 €$ in the next years (Tab. 3).

The smooth operation of the new business required necessary additional working capital arise from the need for available resources and market conditions. Working capital was fully covered by a short-term bank loan. Annual working capital requirements were estimated at $518,776.17 €$ in the first year and ranged between $733,932.59$ and $738,549.82 €$ during the next years.

The administrative, sales, research and development costs were calculated as the 3,5 , and $1 \%$ of the net sales (Deloite, 2016) (Tab. 3). Annual amortization was estimated at 370,192.50 €. The total income for the first year that the business starts operating was $9,515,520 €$. From the second year, the incomes totaled $15,462,720 €$. Net profit in the first year amounted to 3,584,621.70 €, while the annual net profits from the second to tenth year amounted to approximately 7.07 billion. The net profit margins ranged from $37.67 \%$ (first year) to $45.91 \%$ (tenth year) (Tab. 4).

The SWOT analysis revealed that the strongest points of medical cannabis production are the ideal environment and climate conditions in Greece, the possibility of creating mother plants/seeds with high genetic standards, the direct access to the European market and the lower average production from other countries (Folina et al., 2019). On the other hand, the weaknesses are the legislative gaps and a strict institutional framework for providing authorizations/operations, the institutional risk of the license framework for extension and modernization, the participation of different and interested institutions/ ministries/ services as well as the lack of comparative domestic productivity/profitability (EMCDDA, 2018) (Tab. 2). The high and growing demand from the European and international markets, as well as the fact that the medical cannabis operations are easy corporate investments with a rapid decrease of invested capital, can overpass all the weaknesses and threats that arose in medical cannabis production (Hawken, 2013; Folina et al., 2019).

Cannabis market is a fast-growing and emerging market on a European and global scale, governed by a dynamically evolving environment. The worldwide market for cannabis food is about 200 million $€$ showing steady upward trends in recent years (EverBlu Capital, 2017). About 250 million EU citizens and 500 million worldwide even have legal access to cannabis for medical use. According to forecasts, if all European countries legalize cannabis use, the market is estimated to be around $€ 56.2$ billion, of which $€ 35.7$ billion relates to medical cannabis (Prohibition Partners, 2019).

The results of the present study revealed that the 1-hectare medical cannabis operation in Greece is an investment of 4,960,044 €, which requires a working capital of approximately $520,000 €$ in the first year, and from the second to the tenth it needs from 730,000 to $740,000 €$, as well as it is a business with high depreciation. The Net Present Value with a value of $45,425,241.24$ $€$ is positive and the internal rate of return (IRR) is $94.14 \%$ with a discount rate of $4.5 \%$, which 
means that the investment can be characterized as profitable. However, it has to be noted that due to the desktop nature of the current analysis and the limited capacity to undertake consultations to fill in information gaps, some of the assumptions and costs are stronger than others. In order to provide further insight into the medical cannabis industry, particularly in the context of establishing an industry in Greece and differences that may arise in relation to overseas experience, additional analysis would help to inform assumptions that are both significant in driving overall costs and low in confidence in existing estimates.

\section{References}

1. Caulkins J (2010). Estimated Cost of Production for Legalized Cannabis. RAND, Drug Policy Research Center. http://www.rand.org/content/dam/rand/pubs/ working_papers/2010/RAND_WR764.pdf

2. Deloitte (2016). Modelling the cost of medical cannabis. Deloitte Access Economics Pty Ltd, Australia. https:// www2.deloitte.com/content/dam/Deloitte/au/ Documents / Economics/deloitte-au-modelling-costmedicinal-cannabis-230916.pdf Access 06.09.2019.

3. EMCDDA (2018). Cannabis legislation in Europe: An overview. http://www.emcdda.europa.eu/system/files/ publications/4135/TD0217210ENN.pdf

4. EverBlu Capital (2017). Everblu Research - Cannabis industry Report. https://www.everblucapital.com/ research/everblu-research-cannabis-industry-report/ Accessed 06.09.19

5. Freeman TP, Ghoshkova T, Cunningham A, Sedefov R, Griffiths P, Lynskey MT (2018). Increasing potency and price of cannabis in Europe, 2006-16. Addiction, 114(6): 1015-1023.

6. Folina A, Roussis I, Kouneli V, Kakabouki I, Karidogianni S, Bilalis D (2019). Opportunities for cultivation of medical cannabis (Cannabis sativa L.) in Greece. Scientific Papers. Series A. Agronomy, 62(1): 293-300.

7. Hawken A (2013). Economies of Scale in the Production of Cannabis. http://liq.wa.gov/publications/Marijuana/ BOTEC\%20reports/5c-Economies-of-Scale-in-theProduction-of-Cannabis-Final-Revised.pdf

8. Honoré MN, Belmonte-Ureña LJ, Navarro-Velasco A, Camach-Ferre F (2019). Profit Analysis of Papaya Crops under Greenhouses as an Alternative to Traditional Intensive Horticulture in Southeast Spain. International Journal of Environmental Research and Public Health, 16: 2908.

9. Kinghorn AD, Falk H, Gibbons S, Kobayashi J (2017). Phytocannabinoids: Unraveling the Complex Chemistry and Pharmacology of Cannabis sativa. Progress in the Chemistry of Organic Natural Products, 103. Switzerland: Springer.

10. Laate EA (2013). The Economics of Production and Marketing of Greenhouse Crops in Alberta. http:// www1.agric.gov.ab.ca/\$department/deptdocs.nsf/all/ agdex4369/\$file/821-59.pdf?OpenElement

11. Miriello R (2017). Cannabis Botany and Marijuana Horticulture: Naturally Medicinal. An Educational Indoor Growing Literature "The Black \& White Edition(R)" edition. USA: CreateSpace Independent Publishing Platform.

12. Prohibition Partners (2019). The European Cannabis Report, $4^{\text {th }}$ Edition. Prohibition Partners, London, UK. https://prohibitionpartners.com/reports/\# europeancannabis-report-fourth-edition Accessed 06.09.19.

13. Wachira JM, Mshenga PM, Saidi M (2014). Comparison of the Profitability of Small-scale Greenhouse and Open-field Tomato Production Systems in Nakuru-North District, Kenya. Asian Journal of Agricultural Sciences, 6(2): 54-61. 